by SCOLMA. This work has been a major project since the foundation of SCOLMA in 1962; the main volume was published by G. K. Hall in 1977 and lists 17,000 titles of African published periodicals. All volumes give holdings of titles located in British libraries.

Two works also scheduled for publication in 1984 are Bibliography and checklist of African census reports, compiled by John Pinfold, and United Kingdom resources for Southern African studies to be produced in cyclostyled format, being the proceedings of SCOLMA's annual conference in 1983. It describes the Southern African holdings of several prominent libraries in Great Britain including the British Library and includes a contribution on sources in South Africa and the United States by Dr Shula Marks, Director, Institute of Commonwealth Studies.

SCOLMA members are entitled to discounts on commercially published works. For details of these and other SCOLMA publications write to Mrs P. M. Larby, Secretary, SCOLMA, c/o Institute of Commonwealth Studies, 27-28 Russell Square, London WC1B 5DS.

\title{
ALASA: KHOISAN SPECIAL INTEREST GROUP
}

The African Languages Association of Southern Africa (ALASA) was established in 1979 to promote the study of the African languages of southern Africa. More recently, the Khoisan Special Interest Group has been formed to promote research on this important group of languages. In June 1983, the Khoisan SIG published its first newsletter, with research reports by Tony Traill (Phonetic details of Khoisan consonants), Megan Biesele (An ethnobotanical study of !Kung), Wilfred Haacke (The tone of the conditional particle $k a$ in Nama), and Jan Snyman (The Tsowaa of Botswana). This first newsletter was sent to some seventy-five scholars worldwide, who have a known interest in these languages and their speakers. The frequency of future newsletters will depend on the level of support received from members.

Anyone who wishes to become a member of this Special Interest Group and receive regular issues of the newsletter should write to: Dr $\mathrm{C}$. $\mathrm{H}$. Borland, ALASA Khoisan SIG, Dept. of African Languages, University of Cape Town, Rondebosch, 7700 South Africa.

\section{BILLY GRAHAM CENTER ARCHIVES}

The Archives concentrate on documenting Protestant non-denominational evangelization efforts from or in North America, largely since the $1800 \mathrm{~s}$. Among the Archives' holdings on this significant aspect of African history are the records of the African Inland Mission (1900-78), the records of the 1976 Pan Africa Christian Leadership Assembly (1975-8), the records of the Committee to Assist Missionary Education Overseas (1963-75), and the records of the International Christian Broadcasters (1937-78). Also included are the personal papers of and/or oral history interviews with missionaries to the Belgium Congo (and subsequently Zaire), Kenya, Angola, Zambia, and Ethiopia, as well as ephemera of Alfred Tucker, Anglican Bishop in Uganda (1890-1927). 